are probably the only drugs upon which ground or energy should be expended in Great Britain, and the cultivation of the first three is a task for the expert grower. One lesson of the War of 1914-18 which has been forgotten is that the cultivation or collection and the drying of medicinal herbs cannot be undertaken by amateurs efficiently. Inevitably there is great wastage and disappointment. Dr. Ashby emphasizes this in his sections on cultivation, harvesting, preparation and drying.

The problem for the commercial grower is, at bottom, whether he can get a price for his harvest sufficient to pay him to put extra land under cultivation. So far the Ministry of Health has fought shy of guaranteeing prices and the growers have consequently hung back. The yield per acre of ground under medicinal herbs compares at best unfavourably with the yield under foodstuffs, and the grower has in mind always the possibility of an ending of hostilities before his crop is disposed of. This is to-day the obstacle for the home grower : how much more is it likely to prove an obstacle for the Dominion or American grower. Dr. Ashby wisely emphasizes the need for some form of Government protection if Empire cultivation is to flourish.

The Ministry of Health has an advisory committee upon the cultivation of medicinal drugs, but there is still much confusion and unco-ordinated effort. What is needed is (1) active discouragement of the amateur or professional growing or collecting of herbs which have no important therapeutic value; (2) the allocation among home and overseas growers of future requirements of valuable herbs, with guaranteed prices; (3) the co-ordination of research into the conditions of cultivation that will produce the optimum yield of the needed constituents of the herbs.

There is little indication that the present committee has seriously settled down to this triple task, which is indeed less one for the Ministry, however able its advisory committee, than for a body such as the Agricultural Research Council in daily contact with the practical details of modifying plant stocks in required directions and with the relative value to the country of putting land under medicinal herbs or food.

\title{
THE MACKAY RADIO AND TELEGRAPH COMPANY COMMUNICATION SYSTEM
}

\begin{abstract}
COMMANDER M. H. ANDERSON has con1 tributed a paper to Electrical Communication (No. 4, 19, 1941) giving a historical account of the growth of the Mackay Radio and Telegraph Co., the successor of the radio communication business of the Federal Telegraph Company.

The Federal Telegraph Company commenced activities in California in 1909 ; it was organized by a group of Stanford University men who had secured the American rights to the patents of Poulsen and Pedersen of Copenhagen, Denmark. Up to that time the only practical method of radio communication had been by the use of damped waves generated by spark-type equipment. Operation was confined largely to radio communication with ships at sea; the use of radio for point to point communications was very limited, largely because of the inability to cover in a trustworthy way long distances, particularly in the day-time. The are type of high-frequency generator developed by the Danish inventors made possible the use of sustained or undamped waves. This gave the Federal Company a definite advantage, and it established radio telegraph services interconnecting San Francisco, Los Angeles, San Diego and Portland (Oregon) in 1911, and San Francisco and Honolulu in 1912, and competed for business with the existing cable and land line companies.

The immediate success of the long-distance circuit between San Francisco and Honolulu encouraged the United States Navy Department and the Federal Telegraph Company to install in 1912 a Federal are transmitter at the naval radio station at Arlington, Virginia, as a result of which this station was able to communicate with the San Francisco and Honolulu stations, during daylight hours, a feat never before accomplished. Eventually the Navy Department adopted the Federal are system as standard for its services. In 1913, an extensive construetion programme was started, including a chain of high.
\end{abstract}

power naval radio stations for connecting Washington, D.C., with the Canal Zone, California, Hawaii and the Philippines. These ranged in power from 100 to $350 \mathrm{kw}$. and were supplemented by a system of medium-power equipments located at all important naval establishments on United States territory and on ships of the American Fleet. The climax of this development was reached when the Navy Department built the large radio station near Bordeaux, France, during the War of 1914-18, for which the Federal Telegraph Co. supplied two transmitters of $1,000 \mathrm{kw}$. each.

In 1914, the Federal Telegraph Co. entered the marine radio field at San Francisco, enabling ships plying the Pacific to secure daylight communication over great distances. Activity in this field developed rapidly.

When the United States declared war in 1917, Federal Telegraph's radio stations were taken over by the U.S. Navy, but the company continued its domestic telegraph business by utilizing leased wire circuits. In 1921, it constructed a new communication system along the Pacific coast with three complete duplex channels between San Francisco and Portland and three between San Francisco and Los Angeles. Other cities were connected by local lines to this main radio trunk system, so that by 1923 the Federal network included offices in Seattle, Tacoma, Portland, San Francisco, Oakland, Los Angeles and San Diego, besides marine radio stations.

In 1928 the Federal Telegraph Company's system was acquired, along with other properties, by the International Telephone and Telegraph Corporation, the name having been changed to the Mackay Radio and Telegraph Company (California) during the year 1927. The change in ownership occurred at the time when high-frequency vacuum tube transmitters were coming into use, resulting in reduction in the cost 
of establishing radio circuits. The Atlantic and Pacific groups of offices are interconnected by radio trunk circuits between New York and San Francisco, New York and Los Angeles and Chicago and San Francisco. This closely knit domestic system serves main business and population centres and the contiguous districts, totalling more than eight hundred communities. Messages may be filed with Mackay Radio to thirty-one countries and by means of its associated companies it can accept messages to any country in the world.

The third division of Mackay Radio Servicecommunication with ships at sea-is carried out by six powerful coastal stations. A Marine Division is maintained through which ship owners and operators may secure modern ship radio equipment, properly installed and adjusted to obtain the maximum range of communication.

\section{FORTHCOMING EVENTS}

[Meeting marked with an asterisk is open to the public.]

TUESDAY, OCTOBER 28

Royal ANthropological Institute (at 21 Bedford Square, London, W.C.1), at 1.30 p.m.-Mr. E. H. Hunt: "High Places of Sacriflce in Palestine and Petra".

Chadwick Public Lecturf (at the Royal Sanitary Institute, 90 Buckingham Palace Road, London, S.W.1), at, 2.30 p.m.--Mr. J. C.

\section{THURSDAY, OCTOBER 30}

Chemican Socretry (Joint Meeting with the Plastics Group of the Society of Chemical Industry) (at Burlington House, Piccadilly London, W.1), at 2.30 p.m.-Dr. C. Redfarn : "The Constitution of Plastics".

FRIDAY, OCTOBER 31

North-East COAST Institution OF ENGINEERS AND SHIPbUTmDERS (at the Mining Institute, Newcastle-upon-Tyne), at 6 p.m. - Sir
Westcott S. Abell: "Merchant Sea-Power, 1919-1939" (Tenth Westcott S. Abell: “

\section{SATURDAY, NOVEMBER 1}

Geologists' Assocration (at the Geological Society of London, Burlington House, Piccadilly, London, W.1), at 2.30 p.m.-Dr. E. B. Bailey, F.R.S.: "How Scottish Recumbent Folds were Discovered".

\section{APPOINTMENTS VACANT}

Appliontrons are invited for the following appointments on or before the dates mentioned:

GradUate (MAN) To TEACH Chemstry aND Mathematics-The Principal, Dudley and Staffordshire Technical College, The Broadway, Dudley, Staffs. (October 30).

INSPECTOR OF SCHOOLS (WOMAN)-The Director of Education, Education Offices, Deansgate, Manchester 3 (October 31).

Assistant SPEECH Therapist-The Director of Education, Education Department, Newarke Street, Leicester (November 1).

INSTRUCTOR IN WORKSHOP PRACTICE AND PROCESSES in the Oxford Schools of Technology, Art and Commerce-The Chief Education Officer, City Education Office, 77 George Street, Oxford (November 3).

LECTURER IN CHARge OF THE MARINE ENGINEERING SCHOOL of the Hull Municipal Technical College-The Director of Education, Guildhall, Hull (November 3).

Eddcatronal Psychologist to work in the Child Guidance Clinic -The Director of Education, Education Office, Town Hall, Bradford (November 7).

SECRETARy to the Research Association of British Rubber Manufacturers--The Acting Director of Research, 103 Lansdowne Road, Croydon (November 8).

REgIUS Professor OF NATURAL HISTORY in the University of Aberdeen-The Private Secretary, Scottish Office, Fielden House, 10 Great College Street, London, S.W.1 (November 22).

Senior Lecturer in EngINeERING SUbJects in the Halesowen County Technical School-The Secretary Halesowen Higher Education Cormmittee, 21 Gt. Cornbow, Halesowen, Worcestershire.

Psychologrs? (woman)-The Medical Superintendent, Incorporation of National Institutions for Persons requiring Care and Control, Stoke Park Colony, Stapleton, Bristol.

Assistant EDITOR to assist in the publication of "Monthly Science News"-The British Council, 3 Hanover Street, London, W.1.

\section{REPORTS AND OTHER PUBLICATIONS}

(not included in the monthly Books Supplement)

\section{Great Britain and Ireland}

Pharmaceutical Society of Great Britain. Centenary Commemoration, April 15, 1941. Pp. ii +84. (London: Pharmaceutical Society
of Great Britain.) Institution of Automobile Engineers : Automobile Research Com mittee. Tenth Annual Report, July 1st, 1940-June 30, 1941. Pp. 32 (London: Institution of Automobile Engineers.)

Imperial Agricultural Bureaux. Index to Horticultural Abstracts Vols. 1-10, 1931-1940. Compiled by D. Akenhead. Pp. iv +160 (East Malling : Imperiai Bureau of Horticulture and Plantation Crops.)

Proceedings of the Royal Society of Edinburgh. Section A (Mathematical and Physical Sciences). Vol. 61, Part 1, No. 8: Reciprocity, Part 6: The Wave Function of the Meson. By Kathleen Sarginson. Pp. 77-92. 18. 3d. Vol. 61, Part 1, No. 9: On a Certain Variation of the Distributive Law for a Commutative Algebraic Field. By Abraham Robinsohn. Pp. 93-101. 9d. Vol 61, Part 1, No. 10 A New Way of Measuring the Velocity of Light. By Dr. R. A Houstoun. Pp. 102-114. 1s. Section B (Biolngy). Vol. 61, Part 2, bergen. By W. B. Harland. Pp. 119-129+3 plates. 18. 9d. Edinburgh and İondon: Oliver and Boyd.)

Philosophical Transactions of the Royal Society of London. Series A : Mathematical and Physical Sciences. No. 804, Vol. 239: The Asymptotic Expansion of Integral Functions defined by Taylor Series. By Prof. E. M. Wright. Pp. 217-232. 2s. 6d. Series B: Biological Sciences. No. 577, Vol. 231: Cones of Extinct Cycadales from the Jurassic Rocks of Yorkshire. By Prof. Tom M. Harris. Pp. 75-98+ plates 5-6. 5s.6d. (London: Cambridge University Press.) $[1310$ Edinburgh and East of Scotland College of Agrieulture. Calendar for 1941-1942. Pp. 66. (Edinburgh : Edinburgh and East of Scotland College of Agriculture.) (Edinburgh : Edinburgh and East of Scotland Cork Historical and Archæological Society. Historical and ArchæoCork Historical and Archæological Society. Historical and Archæo-
logical Papers, No. 2: Three Centuries of Irish Chemists. Edited by logical Papers, No. 2 : Three Centuries of Irish Chemists. Edited by Talbot Press, Ltd.) 28.6d.

\section{Other Countries}

Indian Central Cotton Committee: Technological Laboratory. Technological Bulletin, Series B, No. 28: A Study of the Inheritance in Mean Fibre-length, Fibre-weight per Unit Length of Fibre-Maturity of Cotton. By R.S. Koshal, A. N. Gulati and Dr. N. A hmad. Pp. 17,


Pp. 38. (Nelson: Cawthron Institute.) Smithsonian Miscellaneous Collęctions. Vol. 101, No. 3 : Environment and Native Subsistence Economics in the Central Great Plains. By Waldo $R$. Wedel. (Publication 3639.) Pp. ii $+29+5$ plates. (Washington, D.C.: Smithsonian Institution.) P. 14+29+5 plat,es. Indian Lac Research Institute. Bulletin No. 44 : Physical Chemistry of Resin Solutions, Part 3: Viscosity of Shellac Solutions in Mixed Solvent. By Santi Ranjan Palit. Pp. 663-674. (Namkum Indian Lac Research Institute.)

Brooklyn Botanic Garden Record. Vol. 30, No. 3: Lilacs in the Brooklyn Botanic Garden, including Classification, Cultivation, Pathology. By Alfred Gundersen. (Guide No. 12.) Pp. 189-224. (Brooklyn, N.Y.: Brooklyn Institute of Arts and Sciences.)
25 cents.

India Meteorological Department. Scientiflc Notes, Vol. 8, No. 92 : Correlation between Frost and the Preceding Meteorological Conditions, Part 2: Jaipur. By Barkat Ali and S. N. Naqvi. Pp. 91-98. 5 annas; 6d. Scientific Notes, Vol. 8, No. 93: Heat Radiation from the Atmosphere at Bombay and its Comparison with that at Poona. By R. Narayanaswami. Pp. 99-112. 9 annas; 10d. (Delhi : Manager
of Publications.)

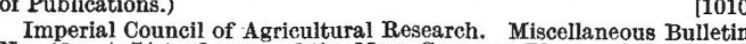
No. 43: A List of some of the More Common Plants of the Desert Areas of Sind, Baluchistan, Rajputana, Kathiawar and South-West Punjab, with their various Iocal Names as far as Available. Compiled by $\mathrm{X}$. Ramchandra Rao. Pp. $\mathrm{v}+45+3$ plates. (Delhi: Manager of Publications.) 2.14 rupees; 4s.9d.

Year-Book of the Royal Asiatic Society of Bengal for 1940. (Vol. 7,

1941.) Pp. 200. (Calcutta: Royal Asiatic Society of Bengal.) 6.8
rupees. rupees.

Records of the Geological Survey of India. Vol. 75, Professional Paper No. 13: A Note on the Bawdwin Mines, Burma. By E. L. G.Clegg. Pp. $14+2$ plates. (Calcutta: Geological Survey of India.) 8 annas;
[1310



Editorial and Publishing Offices

MACMILLAN \& CO., LTD., ST. MARTIN'S STREET, LONDON, W.C.2.

Telephone : Whitehall 883। Telegrams : Phusis Lesquare London Advertisements should be addressed to

T. G. Scott \& Son, Ltd., Three Gables, London Road, Merstham, Surrey Telephone : Merstham 316

The annual subscription rate is $£ 4100$, payable in advance, Inland or Abroad All rights reserved. Registered as a Newspaper at the General Post Offlce 